\title{
Physiological and developmental problems encountered by in vitro cultured plants
}

\author{
Michael W. Bairu • Michael E. Kane
}

Published online: 22 January 2011

(C) Springer Science+Business Media B.V. 2011

After the realization of Haberlandts' theory of totipotency (Krikorian and Berquam 1969 English translation), in vitro culture of plants has become an integral part of advances in plant science research. Plant tissue culture techniques allow for close monitoring and precise manipulation of plant growth and development, the presence of a controlled environment in vitro to analyze specific source(s) of variation and the possibility of manipulating growth at the cell, tissue and organ levels. These benefits, and others, have given tissue culture and its application paramount importance. It is now possible to understand plant growth and its underlying phenomena in vitro. Aspects of plant growth that were barely understood before the advancement of the science of tissue culture, such as the metabolism and interaction of plant hormones, as well as their physiological effects are now well documented. In addition to its role in the advancement of plant science research, plant tissue culture is also contributing enormously in food production, crop improvement, production of secondary products and conservation of endangered species.

The development of tissue culture protocols is a rigorous procedure that involves optimizing the various chemical, physical and environmental factors of growth. It involves

\footnotetext{
M. W. Bairu ( $\square)$

Research Centre for Plant Growth and Development, School of Biological and Conservation Sciences, University of KwaZulu-Natal Pietermaritzburg, Private Bag X01, Scottsville 3209, South Africa e-mail: bairum@ukzn.ac.za

\section{E. Kane}

Environmental Horticulture Department, University of Florida, P.O. Box 110675, Gainesville, FL 32611-0675, USA

e-mail: micropro@ufl.edu
}

growing plants outside their natural environment and growth conditions. The artificial growth conditions are by no means the perfect substitutes for the natural ones. Furthermore, the natural variation in physiology and growth requirement among plant species warrants the need to optimize protocols for individual species. Despite the meticulous efforts involved in growing plants in vitro and the advances made in plant tissue culture, the application of this technique is still hampered by various physiological and developmental problems. The problems range from abnormal growth to increased genetic variability/instability. Papers in this Special Issue report on micropropagation problems related to developmental and physiological aspects such as shoot-tip necrosis (Bairu et al. 2011a), fasciation (Iliev and Kitin 2011), tissue proliferation (Brand 2011), epigenetic changes (Smulders and De Klerk 2011), somaclonal variation (Bairu et al. 2011b), effect of phenolics on rooting (De Klerk et al. 2011), alleviating problems related to caulogenic and rhizogenic processes (Moyo et al. 2011) and assessment of the role of metatopolins in micropropagation and the control of culture abnormalities (Amoo et al. 2011).

\section{Shoot-tip necrosis}

Shoot-tip necrosis is a phenomenon whereby the apical shoot becomes brown and later dies (McCown and Sellmer 1987). The problem of non-pathogenic dieback or shoot-tip necrosis of in vitro cultures has been associated with various culture conditions. See Bairu et al. (2009) for recent review on shoot-tip necrosis. The discrepancy of reports on the role of cytokinins in shoot-tip necrosis is well documented. This is now partly addressed in this Special Issue by Bairu et al. (2011a) via a report on a metabolic study of 
necrotic and normal shoots of Harpagophytum procumbens. The paper reveals changes in cytokinin profiles in relation to cytokinin and auxin treatments on necrotic and normal shoots. It also discusses the role of auxin-cytokinin interactions in relation to shoot-tip necrosis.

\section{Fasciation and tissue proliferation}

Fasciation is abnormal flattening of stems due to failure of the lateral branches to separate from the main stem during growth. Some describe fasciation as fusion of organs due to deviation from normal meristematic processes while others suggest that it is the result of transformation of a single growing point into a line (Clark et al. 1993). Iliev and Kitin (2011) review the origin, morphology and anatomy of fasciation with special emphasis to plants cultured in vitro.

'Tissue proliferation is a disorder primarily found in micropropagated rhododendrons that is characterized by the formation of abnormal callus-like growths, or tumors at or near the crown or base of the plant (Brand and Kiyomoto 1992)'. A review by Brand (2011) provides description, cause and management of tissue proliferation. In addition, an important distinction between tissue proliferation and a crown gall tumor caused by Agrobacterium tumefaciens is highlighted.

\section{Epigenetic changes and somaclonal variation}

Plant tissue culture involves asexual process and, in theory, should result in clonal propagation of true-to-type regenerants. Contrary to this expectation, however, epigenetic changes and somaclonal variation are common occurrences in plant tissue culture. When the objective is mass propagation and generation of uniform plants, such phenomenon are undesirable and often cause serious economic loss.

The distinction between epigenetic changes and somaclonal variation is that the former involves temporary changes in gene expression as a result of events such as change in DNA methylation. Such changes are temporary and often plants reverse to the normal phenotype although some changes may last longer (Brettell and Dennis 1991). Smulders and De Klerk (2011) review the characteristics, cause, detection, rejuvenation and habituation of epigenetic changes with special emphasis to plant tissue culture.

Somaclonal variation on the other hand involves irreversible genetic change originating in cell and tissue cultures (Larkin and Scowcroft 1981). Bairu et al. (2011b) provide a detailed account on the causes and detection methods of somaclonal variation as well as a comprehensive list of practical examples of species affected by somaclonal variation. The role of somaclonal variation as a useful tool in creating novel variants through induced variation is also highlighted.

\section{The role of phenolics and plant growth regulators in alleviating developmental problems}

Limited rooting ability of tissue cultured plants is an important factor challenging the use of tissue culture. After Thimann and Went (1934) remarked that auxin promotes adventitious rooting, several discoveries were made on aspects of rooting. These discoveries range from isolating new rooting hormones (natural and synthetic) to ways of enhancing their activities. In this Special Issue, De Klerk et al. (2011) examine the role of phenolics on rooting of stem slices of apple microshoots and evaluate the root stimulating efficiency of various phenolic compounds and their relationship with auxins.

The development of basal callus is one of the main physiological disorders that affect rooting competence of microplants. There are studies showing the sink effect of this basal callus thereby interfering with many physiological processes by trapping essential growth constituents such as plant growth regulators [see (Bairu et al. 2011a) in this issue] in addition to its effect as a physical barrier. The problem is more severe in woody species where adventitious root and shoot formation are among the major bottlenecks due to recalcitrance to in vitro manipulation. Moyo et al. (2011) investigate the effect of some growth regulators in ameliorating these recalcitrant effects and improving in vitro caulogenic and rhizogenic processes.

Amoo et al. (2011) assess the efficiency of meta-topolins in the micropropagation and alleviation of associated problems on the critically endangered plant-Barleria greenii in comparison with other cytokinins. They report the superiority of meta-topolins over some conventionally used cytokinins and provide some useful structure-function based explanations to the findings.

Collectively, the manuscripts in this Special Issue highlight the severity of the physiological and developmental problems in tissue culture and suggest ways of combating or alleviating the anomalies. They put into perspective the past and present knowledge of the various topics reviewed while indicating future directions. In doing so, they contribute towards our understanding of the discipline of plant tissue culture. We hope that the plant tissue culture community will find these contributions useful.

Acknowledgments The Guest Editors of this Special Issue thank the Authors for their contributions and the Reviewers for their time and constructive scientific inputs. We also thank the Editor-in-Chief of Plant Growth Regulation, Professor J Van Staden, for the opportunity to contribute as Guest Editors. Credit is due to Ms Lee Warren 
(Administrative Assistant), without her hard work this Special Issue would not have been possible.

\section{References}

Amoo SO, Finnie JF, Van Staden J (2011) The role of meta-topolins in alleviating micropropagation problems. Plant Growth Regul

Bairu MW, Stirk WA, Van Staden J (2009) Factors contributing to in vitro shoot-tip necrosis and their physiological interactions. Plant Cell Tissue Organ Cult 98:239-248

Bairu MW, Aremu AO, Van Staden J (2011) Somaclonal variation in plants: causes and detection methods. Plant Growth Regul

Bairu MW, Novák O, Doležal K, Van Staden J (2011) Changes in endogenous cytokinin profiles in micropropagated Harpagophytum procumbens in relation to shoot-tip necrosis and cytokinin treatments. Plant Growth Regul

Brand MH (2011) Tissue proliferation condition in micropropagated ericaceous plants. Plant Growth Regul

Brand M, Kiyomoto R (1992) Abnormal growths on micropropagated elepidote rhododendrons. Comb Proc Int Plant Prop Soc 42:530-534

Brettell RIS, Dennis ES (1991) Reactivation of a silent Ac following tissue culture is associated with heritable alteration in its methylation pattern. Mol Gen Genet 229:365-372
Clark SE, Running MP, Meyerowitz EM (1993) CLAVATA1, a regulator of meristem and flower development in Arabidopsis. Development 119:397-418

De Klerk GJ, Guan H, Huisman P, Marinova S (2011) Effects of phenolic compounds on adventitious root formation and oxidative decarboxylation of applied indoleacetic acid in Malus 'Jork 9'. Plant Growth Regul

Iliev I, Kitin P (2011) Origin, morphology, and anatomy of fasciation in plants cultured in vivo and in vitro. Plant Growth Regul

Krikorian AD, Berquam DL (1969) Plant cell and tissue cultures: the role of Haberlandt. Bot Rev 35:59-88

Larkin P, Scowcroft W (1981) Somaclonal variation-a novel source of variability from cell cultures for plant improvement. Theor Appl Genet 60:197-214

McCown BH, Sellmer JC (1987) General media and vessels suitable for woody plant culture. In: Bonga JM, Durzan L (eds) Cell and tissue culture in forestry: general principles and biotechnology, vol 1. Martinus Nijhoff Publishers, Dordrecht, pp 4-16

Moyo M, Finnie JF, Van Staden J (2011) Recalcitrant effects associated with the development of basal callus-like tissue on caulogenesis and rhizogenesis in Sclerocarya birrea. Plant Growth Regul

Smulders MJM, De Klerk GJ (2011) Epigenetics in plant tissue culture. Plant Growth Regul

Thimann KV, Went FW (1934) On the chemical nature of the root forming hormone. Pro Kon Akad Wetensch 37:456-459 